\title{
Teknik budi daya larva Hermetia illucens (Linnaeus) (Diptera: Stratiomyidae) sebagai sumber protein pakan ternak melalui biokonversi limbah loading ramp dari pabrik CPO
}

\author{
Cultivation technique of Hermetia illucens (Linnaeus) \\ (Diptera: Stratiomyidae) larvae as protein source of feedstuff through \\ bioconversion of loading ramp waste from CPO factory
}

\author{
Agustin Zarkani $^{1 *}$, Miswarti ${ }^{2}$ \\ ${ }^{1}$ Departemen Perlindungan Tanaman, Fakultas Pertanian, Universitas Bengkulu \\ Jalan Raya Kandang Limun, Kota Bengkulu 38371 \\ ${ }^{2}$ Balai Pengkajian Teknologi Pertanian Bengkulu \\ Jalan Irian Km. 6,5 Kelurahan Semarang, Kota Bengkulu 38119
}

(diterima April 2012, disetujui Juni 2012)

\begin{abstract}
ABSTRAK
Larva lalat Hermetia illucens (Linnaeus) (Diptera: Stratiomyidae) merupakan salah satu sumber protein alternatif untuk membuat pelet pakan ternak. Saat ini, produksi larva lalat $H$. illucens masih terbatas karena media budi daya bergantung pada limbah palm kernel meal (PKM). Penelitian ini bertujuan melakukan rekayasa media berbasis limbah loading ramp pabrik minyak kelapa sawit (CPO) sebagai media alternatif untuk budi daya larva H. illucens. Penelitian dilakukan dengan melakukan analisis fisik dan pada kimia media uji. Evaluasi potensi media dilakukan dengan melihat daya dukung hidup limbah loading ramp yang difermentasi menggunakan EM $4^{\circledR}$, mikroba rumen dan pupuk organik cair (POC) serta tanpa fermentasi. Perlakuan pengayaan media loading ramp dengan dedak dan sekam pada rasio $1: 0,25(\mathrm{v} / \mathrm{v}) ; 1: 0,5(\mathrm{v} / \mathrm{v})$ dan $1: 1(\mathrm{v} / \mathrm{v})$ serta penambahan gula kelapa berbentuk padat $1,25 \% ; 2,5 \%$, dan $5 \%$ (b/b). Percobaan disusun dalam Rancangan Acak Kelompok (RAK) melibatkan 20 ekor larva instar ke-2. Larva diinkubasi dalam tabung plastik berdiameter $10 \mathrm{~cm}$ dan tinggi $20 \mathrm{~cm}$ yang mengandung $300 \mathrm{~g}$ media. Respon perbedaan pertumbuhan dan mortalitas dianalisis dengan ANOVA dan uji lanjut least significant differences (LSD) pada taraf 0,05. Analisis ketertarikan dan kesesuaian media dilakukan dengan pengaturan komposisi bahan pengayaan. Hasil penelitian menunjukkan bahwa limbah loading ramp terdiri dari kelopak buah sawit $56 \%$, buah sawit $12 \%$, pasir $20,1 \%$, bebatuan $0,5 \%$, dan lainnya $4,4 \%$. Nutrisi limbah loading ramp mengandung protein 9,8\% dan lemak 10,32\%. Masing-masing komposisi media loading ramp tanpa pengayaan dan dengan pengayaan mampu mendukung tumbuh kembang larva meskipun dengan tingkat beragam. Media dari limbah loading ramp fermentasi POC dengan pengayaan dedak $1: 0,5(\mathrm{v} / \mathrm{v})$ merupakan media budi daya paling potensial.
\end{abstract}

Kata kunci: Hermetia illucens, biokonversi, pakan ternak, limbah loading ramp

\begin{abstract}
Larvae of Hermetia illucens fly (Linnaeus) (Diptera: Stratiomyidae) is an important source of alternative protein and can be used as pellets for feeds. Currently the production of H. illucens larvae is still limited because its rearing depends on palm kernel meal (PKM). The objective of the research is to explore alternative media for rearing, i.e. using loading ramp waste from crude
\end{abstract}

\footnotetext{
*Penulis korespondensi: Agustin Zarkani. Departemen Perlindungan Tanaman, Fakultas Pertanian, Universitas Bengkulu, Jalan Raya Kandang Limun, Kota Bengkulu 38371

Tel: 0736-21290, Faks: 0736-21290, Email: agustinzarkani@ymail.com
} 
palm oil (CPO) factory. The study was conducted using physical-chemical analysis of the media. Evaluation of potential rearing media of loading ramp was done by studying the suitability of loading ramp fermented by $\mathrm{EM} 4^{\circledR}$, rumen microbes, and organic liquid fertilizer and without fermentation. Treatment media was develop with an enrichment ratio of $1: 0.25(\mathrm{v} / \mathrm{v}), 1: 05(\mathrm{v} / \mathrm{v})$, and $1: 1(\mathrm{v} / \mathrm{v})$ for bran and husk, and $1.25 \%, 2.5 \%$, and $5 \%(\mathrm{w} / \mathrm{w})$ for coconut sugar. Each experiment was arranged in complete randomized design using 20 larva of the $2^{\text {nd }}$ instar. Larvas were incubated in plastic with tube with diameter of $10 \mathrm{~cm}$ and $20 \mathrm{~cm}$ in height containing of media $300 \mathrm{~g}$. Response differences in growth and mortality were analyzed by ANOVA and least significant differences (LSD) test at 0.05 levels. Preference and analysis suitability of the media were conducted using material enrichment. Results show that the loading ramp waste contain $9.80 \%$ protein and $10.32 \%$ fat. Although the media are could support growth and development of the larvae at different degree, media from waste fermentation POC loading ramp with bran enrichment $1: 0.5(\mathrm{v} / \mathrm{v})$ is the best media for rearing larva.

Key words: Hermetia illucens, bioconvertion, feedstuff, loading ramp waste

\section{PENDAHULUAN}

Meningkatnya kebutuhan pakan ikan dan unggas dalam bentuk pelet saat ini telah menjadi perhatian serius, seiring dengan keinginan pemerintah Indonesia untuk memenuhi dan meningkatkan gizi protein bagi masyarakat. Data tahun 2009 menunjukkan bahwa pemerintah masih melakukan impor untuk pakan ikan dan unggas hingga mencapai US \$200 juta per tahun (Puslitbangnak 2010).

Salah satu alternatif peluang yang telah dikembangkan adalah biokonversi limbah bungkil sawit atau palm kernel meal (PKM) sebagai media hidup larva lalat Hermetia illucens (Diptera: Stratiomyidae) (Bondari \& Sheppard 1981; Hem et al. 2007). Budi daya lalat muda $H$. illucens ini telah menjadi pakan alternatif karena terbukti dapat menggantikan fungsi tepung ikan sebagai sumber protein pada pelet (Hale 1973; Hadadi et al. 2007).

Menurut Ng \& Chen (2002), tepung larva $H$. illucens memiliki kelebihan dibandingkan dengan tepung protein jenis lainya. Kandungan protein tepung larva $H$. illucens dapat mencapai $40 \%$ hingga $44 \%$ atau hampir dua kali lebih besar dari nilai protein pelet buatan yang hanya mengandung $20 \%$ hingga $25 \%$ protein (Hem et al. 2007; Adi et al. 2009). Keberadaan larva $H$. illucens dinilai relatif aman terhadap manusia, juga dapat mengurangi populasi lalat rumah dan mereduksi kontaminasi limbah terhadap bakteri patogenik Eschercia colli (Lee et al. 1995; Newton et al. 1995).

Larva $H$. illucens memiliki potensi yang besar sebagai pakan dari biokonversi limbah, namun budi daya larva $H$. illucens masih terbatas di daerah yang memiliki pabrik pengolahan inti sawit (kernel), karena budi daya larva H. illucens umumnya masih menggunakan limbah PKM (Hem et al. 2007), sedangkan di daerah lain yang umumnya tidak memiliki pabrik pengolahan inti sawit, budi daya larva $H$. illucens belum dapat dikembangkan secara optimal. Padahal kebutuhan pakan ikan dan unggas di Indonesia cukup tinggi dan bahan bakunya masih tergantung pasokan impor (Puslitbangnak 2010).

Hasil penelitian Zarkani (2010) menunjukkan adanya peluang lain yang dapat dijadikan sebagai media alternatif budi daya larva H. illucens. Salah satu media yang berpotensi itu adalah limbah loading ramp pabrik CPO. Limbah loading ramp merupakan limbah yang dihasilkan saat proses pemasukan tandan buah segar (TBS) ke dalam bak/gerbong/troli sebelum proses perebusan. Setiap satu $\mathrm{kg}$ limbah memiliki peluang untuk menghasilkan 0,3 $\mathrm{kg}$ hingga $0,4 \mathrm{~kg}$ larva. Limbah loading ramp selalu terdapat di setiap pabrik pengolahan $\mathrm{CPO}$, sehingga di setiap tempat pengolahan CPO yang tidak menghasilkan limbah PKM akan terbuka peluang untuk dapat memproduksi massal larva $H$. illucens.

Melalui pengembangan metode budi daya menggunakan limbah loading ramp sebagai pakan alternatif, ketergantungan peternak larva H. illucens terhadap media PKM dapat diatasi. Potensi limbah loading ramp serta aneka teknik fermentasi dan pengayaannya seperti penambahan dedak, sekam, dan gula kelapa belum banyak diketahui sehingga masih diperlukan penelitian lebih mendalam. Penelitian ini bertujuan untuk (a) menganalisis kualitas nutrisi media berbahan baku limbah loading ramp pabrik CPO dengan 
fermentasi menggunakan $\mathrm{EM} 4^{\circledR}$, mikroba rumen, dan pupuk organik cair (POC) sawit serta pengayaan dan tanpa pengayaan sehingga diperoleh potensi awal media bagi pertumbuhan larva, (b) menguji pengaruh perlakuan media berbasis limbah loading ramp dan masing-masing komposisi pengayaan dan tanpa pengayaan bahan terhadap pertumbuhan dan perkembangan serangga $H$. illucens di rumah kaca dan di lapang sehingga didapatkan potensi tumbuh kembang optimal larva dan (c) mencari kombinasi media hidup $H$. illucens berbahan limbah loading ramp dan limbah sawit lainnya dan berbagai bahan pengayaan yang efektif dan efisien untuk budi daya larva lalat $H$. illucens sehingga dapat ditemukan teknik budi daya dengan bahan yang paling murah dan mudah diterapkan.

\section{BAHAN DAN METODE}

\section{Lokasi penelitian}

Penelitian dilakukan di (a) Laboratorium Proteksi, Fakultas Pertanian, Universitas Bengkulu, (b) Laboratorium Balai Pengkajian Teknologi Pertanian (BPTP) Bengkulu, dan (c) Laboratorium Lapang PT. Agriandalas. Penelitian dimulai sejak bulan Maret hingga November 2011.

Limbah loading ramp diambil dari pabrik milik PT. Agriandalas di Kabupaten Seluma dan PT. Bio Nusantara di Kabupaten Bengkulu Tengah, sedangkan spesies serangga uji $H$. illucens diambil dari lokasi pabrik milik PT. Agriandalas, karena H. illucens lebih mudah ditemukan di PT. Bio Nusantara.

\section{Evaluasi potensi limbah loading ramp}

Parameter sifat fisik yang dilihat adalah komposisi bahan penyusun limbah seperti tanah, air, bahan organik, pasir, bebatuan, dan lainnya. Sedangkan sifat kimia bahan yang diukur adalah $\mathrm{C} / \mathrm{N}$ ratio, $\mathrm{pH}$, protein total, lemak, $\mathrm{N}, \mathrm{P}, \mathrm{K}$, dan $\mathrm{C}$. Sifat kimia bahan didiukur dengan metode yang sesuai di Laboratorium BPTP Bengkulu.

Parameter yang digunakan dalam analisis parameter lingkungan mikro-makro adalah suhu, kelembaban, curuh hujan, dan ketinggian tempat dimana limbah loading ramp berada. Pengukuran suhu dilakukan dengan menggunakan termometer digital lapang (THC1 Prui Electronic), kelembapan dengan hygrometer (Asby Singapore Pte Ltd), sedangkan data curuh hujan dilakukan dengan mencatat jumlah hari hujan setiap minggunya.

\section{Uji kelayakan bahan media}

Evaluasi jenis fermentasi limbah loading ramp dilakukan dengan membandingkan hasil berbagai bahan fermentator seperti EM $4{ }^{\circledR}$ (merek dagang PT. Songgolangit Persada), mikroba rumen (biakan Laboratorium Proteksi, Fakultas Pertanian, Universitas Bengkulu), dan pupuk organik cair (POC) sawit. POC sawit diperoleh dengan cara mencari air rendaman kompos matang TKS dengan air pada perbandingan $1: 10$ selama 4 hari. Fermentasi dilakukan dengan cara mencampurkan $10 \%(\mathrm{v} / \mathrm{b})$ bahan fermentator ke dalam limbah loading ramp dan kemudian media diinkubasi dalam bak plastik selama 7 hari.

Hasil uji media terfermentasi yang terbaik selanjutnya difaktorialkan dengan aneka teknik penambahan bahan pengayaan seperti dedak, sekam dan gula merah kelapa dibandingkan dengan fermentasi secara alami PKM sebagai media hidup utama. Pengujian potensi aneka komposisi pengayaan media terhadap larva $H$. illucens dilakukan dengan teknik pilihan dan tanpa pilihan. Perlakuan produksi media dilakukan dengan ratio pengayaan $1: 0,25(\mathrm{v} / \mathrm{v}) ; 1: 0,5(\mathrm{v} / \mathrm{v}) ;$ dan $1: 1$ (v/v) untuk dedak dan sekam serta $1,25 \%(\mathrm{~b} / \mathrm{b})$; $2,5 \%(\mathrm{~b} / \mathrm{b})$; dan $5 \%(\mathrm{~b} / \mathrm{b})$ untuk gula kelapa merah padat. Uji tanpa pilihan pakan dilakukan di rumah kaca dalam kotak-kotak pemeliharaan dan uji pilihan dilakukan di lapangan masing-masing tiga ulangan dengan mengacu terhadap hasil terbaik pada uji tanpa pilihan. Percobaan disusun dalam Rancangan Acak Kelompok dengan melibatkan 20 ekor larva instar ke-2. Larva diinkubasi dalam tabung plastik berdiameter $10 \mathrm{~cm}$ dan tinggi $20 \mathrm{~cm}$ yang mengandung $300 \mathrm{~g}$ media. Respon perbedaan pertumbuhan dan mortalitas dianalisis dengan ANOVA dan uji lanjut least significant differences (LSD) pada taraf 0,05. Pengujian dilakukan di Laboratorium Proteksi Tanaman, Fakultas Pertanian, Universitas Bengkulu.

\section{Analisis ketertarikan dan kesesuaian media melalui pengaturan komposisi bahan pengayaan}

Jenis media yang terbaik dari hasil uji kelayakan bahan dilakukan uji perbaikan ulang 
komposisi. Perbaikan komposisi terdiri dari jenis bahan pengayaan yaitu dedak, sekam, dan gula merah kelapa dengan perbandingan yang lebih ekonomis. Pengujian disusun dalam Rancangan Acak Kelompok (RAK) dengan tiga ulangan. Respon perbedaan pertumbuhan dan kebugaran seperti jumlah telur (perhitungan menggunakan bantuan Program ImageJ) dan sex ratio dianalisis dengan ANOVA dan uji lanjut LSD pada taraf 0,05 . Pengujian dilakukan di sekitar area pabrik CPO PT. Agriandalas.

\section{Analisis media kandidat yang potensial}

Analisis media potensial dilakukan dengan membandingkan aneka jenis media loading ramp yang digunakan terhadap preferensi imago meletakkan telur, bobot larva, dan mortalitas. Media dengan perlakuan yang paling sederhana, namun memberikan hasil yang dominan ditetapkan sebagai kandidat terbaik.

\section{HASIL}

\section{Potensi limbah loading ramp}

Limbah loading ramp pabrik CPO merupakan limbah organik industri pabrik kelapa sawit yang belum dimanfaatkan secara optimal. Di pabrik CPO milik PT. Agriandalas dengan kapasitas produksi 60 ton per jam dapat menghasilkan 3-4 ton limbah loading ramp setiap harinya (Gambar 1). Komposisi kandungan limbah loading ramp didominasi oleh kelopak buah sawit yang terlepas

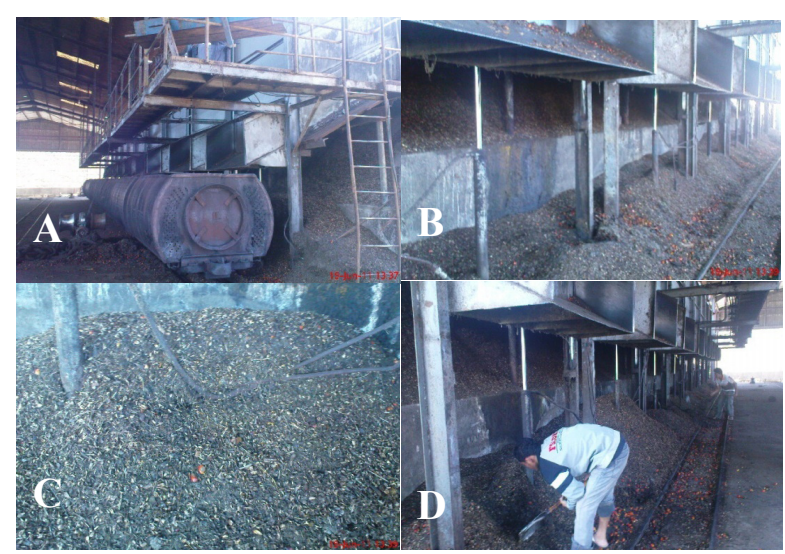

Gambar 1. Limbah loading ramp pabrik CPO. A: proses pamasukkan buah ke dalam troli; B: limbah yang menumpuk di bawah bak penampungan buah; C: limbah loading ramp didominasi oleh kelopak buah; D: limbah loading ramp dibersihkan dan dibuang setiap hari.
(56\%) dan buah sawit/brondol (12\%) (Tabel 1). Limbah loading ramp yang membusuk pada waktu \pm 7 hari kemudian menjadi media yang sesuai untuk kehidupan larva H. illucens.

Limbah loading ramp memiliki kandungan nutrisi berupa protein sekitar 9,81\% dan lemak kasar sekitar 10,32\%. Kandungan nutrisi ini lebih rendah dari limbah CPO lainnya seperti ampas bungkil atau palm kernel meal (PKM) dan solid. Meskipun demikian limbah loading ramp masih dapat mendukung pertumbuhan larva $H$. illucens. Fermentasi limbah dengan menggunakan POC sawit dapat meningkatkan kandungan protein, namun menurunkan kandungan lemak total bahan (Tabel 2).

Di lokasi pabrik CPO milik PT. Agriandalas dan PT. Bio Nusantara yang banyak ditemui populasi larva, suhu lingkungan sekitar pabrik cukup hangat yaitu mencapai $31,75^{\circ} \mathrm{C}$ (Tabel 3 ).

Tabel 1. Analisis fisik bahan limbah loading ramp

\begin{tabular}{lc}
\hline Komposisi limbah loading ramp & Rata-rata $(\% \mathrm{v} / \mathrm{v})$ \\
\hline Tanah & 7,00 \\
Bahan organik buah: & \\
- Brondol buah sawit & 12,00 \\
- Kelopak buah sawit & 56,00 \\
Pasir & 20,10 \\
Bebatuan & 0,50 \\
Lainnya (daun, kayu) & 4,40 \\
\hline
\end{tabular}

Tabel 2. Analisis kimia bahan limbah loading ramp tanpa fermentasi POC dan dengan fermentasi POC

\begin{tabular}{lcc}
\hline \multirow{2}{*}{ Komposisi } & \multicolumn{2}{c}{ Jenis bahan } \\
\cline { 2 - 3 } & Loading ramp & $\begin{array}{c}\text { Loading ramp } \\
\text { fermentasi POC }\end{array}$ \\
\hline C/N ratio & 15 & 12 \\
pH & 6,7 & 7,1 \\
Protein total (\%) & 9,81 & 9,95 \\
Lemak total (\%) & 10,32 & 8,01 \\
$\mathrm{~N}(\%)$ & 1,04 & 0,98 \\
$\mathrm{P}(\%)$ & 0,25 & 0,28 \\
$\mathrm{~K}(\%)$ & 0,92 & 0,99 \\
\hline
\end{tabular}

Tabel 3. Parameter lingkungan makro-mikro lingkungan lalat Hermetia illucens

\begin{tabular}{lc}
\hline Parameter mikro-makro & Hasil rata-rata \\
\hline Suhu $\left({ }^{\circ} \mathrm{C}\right)$ & 31,75 \\
RH $(\%)$ & 69,80 \\
Curah hujan (mmHg) & 17 \\
Ketinggian tempat $(\mathrm{m}$ dpl) & 25 \\
\hline
\end{tabular}


Suhu yang cukup tinggi dari sekitarnya ini terjadi karena lokasi penumpukan limbah berdekatan dengan ketel perebusan dan juga asupan panas sinar matahari dari atap pabrik yang umumnya tidak memiliki langit-langit sebagai peredam panas. Meskipun demikian kondisi ini tidak mempengaruhi imago untuk meletakkan telur (oviposisi). Suhu limbah loading ramp yang terfermentasi secara alami juga cukup tinggi yaitu rata-rata $30,25^{\circ} \mathrm{C}$. Cukup tingginya suhu media ini lebih disebabkan oleh proses pengomposan yang masih berlangsung dan juga adanya aktifitas respirasi larva.

\section{Kelayakan limbah loding ramp sebagai media hidup larva}

Kelayakan awal media sebagai perkembangan larva dilakukan melalui evaluasi tiga jenis fermentator limbah loading ramp yaitu EM4, mikroba rumen, dan POC sawit. Uji ANOVA menunjukkan bahwa jenis media tidak berpengaruh pada panjang, lebar dan bobot larva $H$. illucens, namun berpengaruh sangat nyata terhadap jumlah kematian larva (Tabel 4). Kematian larva lebih sedikit terjadi pada media fermentasi loading ramp dengan POC dan tanpa fermentasi yaitu masingmasing sebesar $5 \%$ dan $8 \%$.

Uji lanjut dengan pengayaan media utama yaitu fermentasi loading ramp dan tanpa fermentasi dengan aneka teknik penambahan bahan pengayaan seperti dedak, sekam, dan gula memberikan hasil yang beragam terhadap mortalitas dan bobot larva (Tabel 5). Hasil yang terbaik adalah pengayaan media dengan penambahan dedak $1: 1$ dan $1: 0,5$ dengan bobot larva berurutan yaitu $0,1556 \mathrm{mg}$ dan $0,1543 \mathrm{mg}$ untuk media loading ramp non fermentasi serta $0,1558 \mathrm{mg}$ dan 0,1544 mg untuk media loading ramp fermentasi POC. Meskipun pengayaan media loading ramp dengan penambahan dedak memberikan hasil yang terbaik, hasil ini masih relatif lebih rendah dan berbeda nyata bila dibandingkan dengan media hidup larva menggunakan PKM. Perbedaan ini lebih disebabkan oleh nilai nutrisi PKM yang lebih baik dari media loading ramp. Kualitas dan kuantitas pakan sangat mempengaruhi kandungan nutrisi tubuh serta keberlangsungan hidup serangga pada setiap instar dan generasi yang akan datang.

Pengayaan media utama dengan dedak pada perbandingan $1: 1$ dan $1: 0,5$ secara statistika tidak memberikan pengaruh terhadap mortalitas dan bobot larva, namun berbeda nyata pada perbandingan $1: 0,25$ sehingga pengaturan pada perbandingan $1: 0,25$ tidak berpotensial untuk dikembangkan. Media loading ramp dengan pengayaan dedak $1: 0,5$ selanjutnya ditetapkan sebagai kandidat potensial media hidup larva.

Hasil analisis kandungan protein dan lemak terhadap larva instar ke-5 mendapatkan pola yang acak (Tabel 6). Tidak adanya pola kandungan nutrisi yang sinkron terhadap jenis media yang digunakan menunjukkan bahwa larva masih mampu memanfaatkan media yang diujikan. Walaupun demikian kandungan nutrisi makanan rendah dan kurang terkadang akan berdampak pada bobot dan lama fase instar serangga.

Uji preferensi imago terhadap oviposisi telur dengan teknik pilihan mendapatkan jumlah telur yang beragam (Tabel 7). Meskipun pada uji potensi perkembangan larva terhadap masingmasing media memiliki potensi yang sama sebagai media hidup larva (Tabel 6), media loading ramp yang difermentasi dengan POC dan pengayaan lebih disukai imago untuk meletakkan telurnya dibandingkan dengan media lainnya selain PKM.

\section{Analisis media kandidat yang potensial}

Dari berbagai analisis terhadap aneka media limbah loading ramp yang telah dilakukan sebelumnya, maka media hidup larva yang berasal

Tabel 4. Uji kelayakan media utama dengan tiga jenis fermentasi

\begin{tabular}{lcccc}
\hline \multirow{2}{*}{ Perlakuan } & \multicolumn{4}{c}{ Pengukuran terhadap instar 5 akhir } \\
\cline { 2 - 5 } & Mortalitas (\%) & Panjang (mm) & Lebar (mm) & Bobot (mg) \\
\hline Loading ramp & $8 \mathrm{a}$ & $19,66 \mathrm{a}$ & $5,28 \mathrm{a}$ & $0,1504 \mathrm{a}$ \\
Loading ramp + POC & $5 \mathrm{ac}$ & $19,85 \mathrm{a}$ & $5,27 \mathrm{a}$ & $0,1496 \mathrm{a}$ \\
Loading ramp + Rumen & $20 \mathrm{~b}$ & $19,66 \mathrm{a}$ & $5,32 \mathrm{a}$ & $0,1518 \mathrm{a}$ \\
Loading ramp + EM4 & $20 \mathrm{~b}$ & $19,85 \mathrm{a}$ & $5,26 \mathrm{a}$ & $0,1468 \mathrm{a}$ \\
PKM & $2 \mathrm{c}$ & $19,82 \mathrm{a}$ & $5,33 \mathrm{a}$ & $0,1522 \mathrm{a}$ \\
\hline
\end{tabular}


dari limbah loading ramp fermentasi POC dengan pengayaan dedak $1: 0,5(\mathrm{v} / \mathrm{v})$ merupakan kandidat utama yang potensial (Tabel 8). Meskipun demikian, media ini masih belum dapat menyamai potensi media PKM terutama pada tingkat preferensi oviposisinya.

Tabel 5. Mortalitas dan bobot larva Hermetia illucens dengan menggunakan aneka jenis pengayaan media dengan teknik tanpa pilihan

\begin{tabular}{|c|c|c|}
\hline \multirow{2}{*}{ Perlakuan } & \multicolumn{2}{|c|}{$\begin{array}{c}\text { Pengukuran } \\
\text { terhadap instar } 5 \text { akhir }\end{array}$} \\
\hline & $\begin{array}{c}\text { Mortalitas } \\
(\%)\end{array}$ & $\begin{array}{c}\text { Bobot } \\
\text { (mg) }\end{array}$ \\
\hline PKM & $0,00 \mathrm{a}$ & $0,1609 a$ \\
\hline \multicolumn{3}{|c|}{ Loading ramp } \\
\hline \multicolumn{3}{|l|}{ Dedak } \\
\hline $1: 1$ & $0,00 \mathrm{a}$ & $0,1556 \mathrm{~b}$ \\
\hline $1: 0,5$ & $0,00 \mathrm{a}$ & $0,1543 \mathrm{~b}$ \\
\hline $1: 0,25$ & $1,67 \mathrm{ab}$ & $0,1510 \mathrm{c}$ \\
\hline \multicolumn{3}{|l|}{ Sekam } \\
\hline $1: 1$ & $3,33 \mathrm{ab}$ & $0,1501 \mathrm{c}$ \\
\hline $1: 0,5$ & $1,67 \mathrm{ab}$ & $0,1491 \mathrm{c}$ \\
\hline $1: 0,25$ & $5,00 \mathrm{~b}$ & $0,1510 \mathrm{c}$ \\
\hline \multicolumn{3}{|l|}{ Gula } \\
\hline $5,00 \%$ & $1,67 \mathrm{ab}$ & $0,1507 \mathrm{c}$ \\
\hline $2,50 \%$ & $3,33 \mathrm{ab}$ & $0,1489 \mathrm{c}$ \\
\hline $1,25 \%$ & $5,00 \mathrm{~b}$ & $0,1509 \mathrm{c}$ \\
\hline \multicolumn{3}{|c|}{ Loading ramp + POC } \\
\hline \multicolumn{3}{|l|}{ Dedak } \\
\hline $1: 1$ & $0,00 \mathrm{a}$ & $0,1558 \mathrm{~b}$ \\
\hline $1: 0,5$ & $0,00 \mathrm{a}$ & $0,1544 \mathrm{~b}$ \\
\hline $1: 0,25$ & $3,33 \mathrm{ab}$ & $0,1512 \mathrm{c}$ \\
\hline \multicolumn{3}{|l|}{ Sekam } \\
\hline $1: 1$ & $1,67 \mathrm{ab}$ & $0,1504 \mathrm{c}$ \\
\hline $1: 0,5$ & $1,67 \mathrm{ab}$ & $0,1493 \mathrm{c}$ \\
\hline $1: 0,25$ & $3,33 \mathrm{ab}$ & $0,1512 \mathrm{c}$ \\
\hline \multicolumn{3}{|l|}{ Gula } \\
\hline $5,00 \%$ & $3,33 \mathrm{ab}$ & $0,1510 \mathrm{c}$ \\
\hline $2,50 \%$ & $5,00 \mathrm{~b}$ & $0,1491 \mathrm{c}$ \\
\hline $1,25 \%$ & $5,00 \mathrm{~b}$ & $0,1510 \mathrm{c}$ \\
\hline
\end{tabular}

Tabel 6. Kandungan protein dan lemak total larva Hermetia illucens

\begin{tabular}{lcc}
\hline \multirow{2}{*}{ Perlakuan } & \multicolumn{2}{c}{$\begin{array}{c}\text { Pengukuran terhadap } \\
\text { larva instar 5 }\end{array}$} \\
\cline { 2 - 3 } & Protein (\%) & Lemak (\%) \\
\hline PKM & 43,55 & 27,55 \\
Loading Ramp & & \\
Dedak 1:1 & 43,53 & 26,85 \\
Dedak 1:0,5 & 43,55 & 26,62 \\
Loading Ramp + POC & & \\
Dedak 1:1 & 43,52 & 26,70 \\
Dedak 1:0,5 & 43,53 & 26,71 \\
\hline
\end{tabular}

\section{PEMBAHASAN}

Limbah loading ramp yang mayoritas terdiri dari kelopak buah sawit dan buah sawit yang terlepas, merupakan limbah yang pertama kali dihasilkan dalam proses produksi CPO. Sekalipun limbah loading ramp tidak termasuk dalam kategori limbah utama proses produksi CPO, jumlah limbah yang dihasilkan cukup tinggi yaitu mencapai 1-4 ton per hari tergantung pada kapasitas produksi pabrik dan kualitas buah yang digunakan sebagai bahan baku CPO. Umumnya pihak pengelola pabrik membersihkan dan membuang limbah ini serta menumpuknya di sekitar areal pabrik tanpa penanganan khusus.

Kandungan protein dan lemak limbah loading ramp lebih rendah dari limbah CPO lainnya seperti PKM dan solid. Sundu \& Dingle (2003) melaporkan PKM mengandung protein $16 \%$ hingga $17 \%$ dan lemak 13\% hingga 15\%, sedangkan limbah

Tabel 7. Data produksi telur rata-rata dan sex ratio imago Hermetia illucens

\begin{tabular}{lcc}
\hline \multirow{2}{*}{ Perlakuan } & \multicolumn{2}{c}{$\begin{array}{c}\text { Pengukuran terhadap } \\
\text { imago }\end{array}$} \\
\cline { 2 - 3 } & Telur rata-rata & Sex ratio \\
\hline PKM & 171 & $1 / 1$ \\
Loading ramp tanpa & 20 & $1 / 0,75$ \\
pengayaan & & \\
Loading ramp & & \\
Dedak 1: 1 & 133 & $1 / 0,76$ \\
Dedak 1:0,5 & 99 & $1 / 0,75$ \\
& & $1 / 0,71$ \\
Loading ramp + POC & & $1 / 0,77$ \\
Dedak 1: 1 & 138 & \\
Dedak 1 : 0,5 & 137 & \\
\hline
\end{tabular}

Tabel 8. Analisis potensi media sebagai kandidiat media hidup Hermetia illucens

\begin{tabular}{lccc}
\hline Jenis media & $\begin{array}{c}\text { Preferensi } \\
\text { oviposisi }\end{array}$ & $\begin{array}{c}\text { Bobot } \\
(\mathrm{mg})\end{array}$ & $\begin{array}{c}\text { Mortalitas } \\
(\%)\end{array}$ \\
\hline PKM & 171 & 0,1609 & 0 \\
$\begin{array}{l}\text { Loading ramp tanpa } \\
\text { pengayaan }\end{array}$ & 20 & 0,1504 & 8 \\
Loading ramp & & & \\
$\quad$ Dedak 1: 1 & 133 & 0,1556 & 0 \\
$\quad$ Dedak 1 : 0,5 & 99 & 0,1543 & 0 \\
Loading ramp + POC & & & \\
$\quad$ Dedak 1: & 138 & 0,1558 & 0 \\
$\quad$ Dedak 1 : 0,5 & 137 & 0,1544 & 0 \\
\hline
\end{tabular}


solid umumnya mengandung protein $12,63 \%$ dan lemak 7,12\% (Hadadi et al. 2007). Akan tetapi, limbah loading ramp masih cukup mendukung pertumbuhan dan perkembangan larva $H$. illucens. Meningkatnya kandungan protein dan menurunnya kandungan lemak pada limbah loading ramp yang diperlakukan dengan fermentasi POC lebih disebabkan oleh adanya tambahan protein dari tubuh mikroba pengurai senyawa lemak. Proses fermentasi ini menjadi penting karena protein yang tersedia dapat menjadi sumber makanan utama serangga dalam pemenuhan kebutuhan asam amino terutama bagi serangga muda. Lemak lebih diperlukan sebagai sumber energi tertinggi dan sekaligus untuk meregulasi metabolisme (Chapman 1998).

Peningkatan suhu selama proses fermentasi limbah loading ramp, yaitu rata-rata $30,25^{\circ} \mathrm{C}$, berguna untuk mendukung optimalisasi pertumbuhan larva. Booth \& Sheppard (1984) menyatakan bahwa suhu yang lebih hangat, yaitu diatas $30^{\circ} \mathrm{C}$, dapat menyebabkan $H$. illucens lebih aktif dan produktif. Penelitian yang pernah dilakukan Tomberlin et al. (2009) menemukan suhu optimal perkembangan larva $H$. illucens sekitar $30^{\circ} \mathrm{C}$ dan hampir tidak ada pupa yang sintas pada suhu $36^{\circ} \mathrm{C}$. Hal yang sama juga dilaporkan Rachmawati et al. (2010), yaitu suhu mempengaruhi masa inkubasi telur $H$. illucens yang cenderung berlangsung lebih singkat satu hari daripada masa inkubasi yang pernah dilakukan oleh para peneliti di beragam tempat lainnya.

Meskipun proses fermentasi dapat meningkatkan nutrisi media limbah loading ramp, kajian yang lebih terperinci terhadap jenis fermentator yang digunakan masih perlu dilakukan mengingat fermentasi limbah loading ramp menggunakan EM4 ${ }^{\circledR}$ dan mikroba rumen dapat mengakibatkan mortalitas larva yang lebih besar dibandingkan dengan POC. Kejadian mortalitas ini diduga muncul karena EM4 ${ }^{\circledR}$ dan mikroba rumen mengandung mikroba yang bersifat toksik bagi larva seperti bakteri dan jamur entomopatogenik yang pernah dilaporkan sebelumnya oleh Doutt (1964).

Pengayaan media dengan penambahan dedak $50 \%$ lebih dianjurkan dibandingkan dengan penambahan sekam pada perbandingan yang sama dan penambahan gula kelapa pada taraf $1,25 \% ; 2,5 \%$; dan $5 \%$. Penambahan dedak yang lebih dari separuh jumlah limbah loading ramp tidak memberikan dampak yang signifikan terhadap bobot dan mortalitas larva. Lebih lanjut, pengayaan media dengan penambahan dedak lebih direkomendasikan karena dapat mempengaruhi kesukaan imago betina untuk meletakkan telurnya. Media loading ramp tanpa pengayaan lebih tidak disukai imago betina dalam meletakkan telur. Kemungkinan munculnya perilaku oviposisi positif ini lebih disebabkan oleh senyawa antraktan aromatik nutrisi media yang muncul saat proses fermentasi. Godfray (1994) menyatakan bahwa senyawa organik aromatik dapat menjadi petanda bagi imago untuk melakukan oviposisi.

Diduga kuat bahwa kualitas media hidup larva dapat menyebabkan perbedaan jenis kelamin imago lalat $H$. illucens. Perbedaan sex ratio dapat terjadi apabila jumlah makanan yang tersedia kurang, dimana jenis kelamin jantan akan muncul lebih mendominasi. Kejadian ini terlihat bila kita membandingkan sex ratio imago yang muncul dari media berbahan dasar PKM lebih seragam bila dibandingkan dengan loading ramp. Meskipun kualitas media mempengaruhi jenis kelamin imago, kajian yang lebih lanjut masih perlu dilakukan karena kasus dominasi sex ratio ini lebih banyak dilaporkan terjadi pada seranggaserangga parasitoid Ordo Hymenoptera (Flenders 1965; Godfray 1994).

Media yang berasal dari fermentasi limbah loading ramp dengan POC dan penambahan dedak $50 \%(\mathrm{v} / \mathrm{v})$ lebih direkomendasikan sebagai media kandidat potensial mengingat proses penyiapan media yang cukup mudah dan memberikan hasil yang dominan lebih baik. Meskipun demikian, media kandidiat ini memiliki kemampuan daya dukung terhadap potensi hidup larva yang masih lebih rendah bila dibandingkan dengan media PKM.

\section{KESIMPULAN}

Limbah loading ramp pabrik CPO memiliki potensi sebagai media hidup larva $H$. illucens dengan kandungan nutrisi berupa protein sekitar 9,81\% dan lemak kasar sekitar 10,32\%. Perlakuan media berbasis limbah loading ramp dengan perlakukan pengayaan dan tanpa pengayaan 1 : 0,$25 ; 1: 0,5$; dan $1: 1$ untuk dedak dan sekam serta $1,25 \% ; 2,5 \%$; dan $5 \%$ untuk gula kelapa serta 
dengan fermentasi menggunakan EM4, mikroba rumen, dan pupuk organik cair (POC) telah merubah nilai nutrisi limbah loading ramp serta mampu mendukung tumbuh kembang larva meski dengan tingkat yang beragam.

Media yang berasal dari limbah loading ramp fermentasi POC dengan pengayaan dedak 1 : 0,5 merupakan media kandidat potensial untuk rearing larva $H$. illucens. Meskipun demikian potensi media kandidat ini masih lebih rendah bila dibandingkan dengan media PKM yang umumnya sudah digunakan untuk memproduksi massal larva H. illucens.

\section{UCAPAN TERIMA KASIH}

Terima kasih kepada Litbang, Kementrian Pertanian, Republik Indonesia atas bantuan pendanaan yang diberikan untuk menyelesaikan penelitian. Penelitian ini merupakan bagian dari penelitian KKP3T Tahun 2011.

\section{DAFTAR PUSTAKA}

Adi CH, Mundayana Y, Hanif S, Wibowo KT, Herry, Surahman A, Ridwan E. 2009. Produksi pelet berbasis bahan larva untuk budi daya ikan. Available at: http/bbpbat.go.id. [accessed 28 January 2011].

Bondari K, Sheppard DC. 1981. Soldier fly larvae as feed in commercial fish production. Aquaculture 24:103109. http://dx.doi.org/10.1016/0044-8486(81)900478.

Booth DC, Sheppard C. 1984. Oviposition of the black soldier fly, Hermetia illucens (Diptera: Stratiomyidae): eggs, masses, timing, and site characteristics. Environmental Entomology 13:421-423.

Chapman RF. 1998. The Insects: Structure and Function. $4^{\text {th }}$ ed. Cambridge: Cambridge University Press. Bondari K, Sheppard DC. 1981. Soldier fly larvae as feed in commercial fish production. Aquaculture 24:103-109. http:// dx.doi.org/10.1017/CBO9780511818202.

Doutt RL. 1964. Biological characteristics of Entomophagous adults. In: DeBach P (Ed.), Biological Control of Insects Pests and Weeds. pp. 145-167. London: Chapman and Hall.

Flenders SE. 1965. On the sexuality and sex rations of hymenopterous population. American Naturalis 99:489-494. http://dx.doi.org/10.1086/282393.

Godfray HCJ. 1994. Parasitoids: Behavioral and Evolutionary Ecology. New Jersey: Princeton University Press.
Hadadi A, Herry, Setyorini, Surahman A, Ridwan E. 2007. Pemanfaatan limbah sawit untuk bahan pakan ikan. Jurnal Budidaya Air Tawar 4:11-18.

Hale OM. 1973. Dried Hermetia illucens larvae (Stratiomyidae) as a feed additive for poultry. Journal of the Georgia Entomological Society 8:16-20.

Hem S, Rini M, Chumaidi, Maskur, Hadadi A, Supriyadi, Ediwarman, Larue M, Pouyaud L. 2007. Volarization of palm kernel meal (PKM), a by-product from palm oil agro industry, via bioconversion: a natural process of particular interest for the development of aquaculture in Indonesia. In: International Conference on oil palm and environment (Bali, 15-16 November 2007). Bali: ICOPE

Lee HL, Chandrawathani P, Wong WY, Tharam S, Lim WY. 1995. A case of human enteric myiasis due to larvae of Hermetia illucens (Family Stratiomyidae): first report in Malaysia. Malaysian Journal of Pathology 17:109-111.

Newton GL, Sheppard DC, Thompson SA, Savage SI. 1995. The soldier fly, a beneficial insect: house fly control, manure volume reduction and nutrient recycling. In: H. H. Van Horn (Ed.), Proceedings Nuisance Concerns in Animal Manure Management: Odors and Flies Conference (Gainesville, 21-22 March 1995). pp. 106-116. Gainesville: University of Florida.

$\mathrm{Ng} \mathrm{WK}$, Chen ML. 2002. Replacement of soybean meal with palm kernel meal in practical diets for hybrids Asian-Africancatfish. Journal of Applied Aquaculture 12:67-76. http://dx.doi.org/10.1300/ J028v12n04_06.

[Puslitbangnak] Pusat Penelitian dan Pengembangan Peternakan. 2010. Gunakan Pakan Lokal untuk Ternak Unggas. Bogor: Puslitbangnak.

Rachmawati, Buchori D, Hidayat P, Hem S, Fahmi MR. 2010. Perkembangan dan kandungan nutrisi larva Hermetia illucens (Linnaeus) (Diptera: Stratiomyidae) pada bungkil Kelapa Sawit. Jurnal Entomologi Indonesia 7:28-41.

Sundu B, Dingle J. 2003. Use of enzymes to improve the nutritional value of palm kernel meal and copra meal. In: Dingle J.G (Ed.), Proceeding of Queensland Poultry Science Symposium Australia (Queensland, 24 July 2003). pp. 1-15. Gatton, Queensland: World's Poultry Science Association.

Tomberlin JK, Adler PH, Myers HM. 2009. Development of the black soldier fly (Diptera: Stratiomyidae) in relation to temperature. Environmental Entomology 38:930-934. http:// dx.doi.org/10.1603/022.038.0347.

Zarkani A. 2010. Peluang budi daya larva Hermetia illucens berbasis aneka limbah sawit. In: Poster Session Seminar Nasional Biomass Energi Kelapa Sawit (Bengkulu, 20 Desember 2010). Bengkulu: Lemlit UNIB. 